\title{
Kotimaisten viljojen ja maissin sulavuus ja rehuarvo eri ikäisillä kalkkunoilla
}

Samu Palander, Matti Näsi ja Sari Järvinen

Kotieläintieteen laitos, PL 28, 00014 Helsingin yliopisto, samu.palander@helsinki.fi, matti.nasi@helsinki.fi, sari.s.jarvinen@helsinki.fi

\section{Johdanto}

Viljojen rehuarvoa siipikarjalle heikentävät usein ravitsemuksellisiksi haitta-aineiksi luokiteltavat hemiselluloosapolysakkaridit, kuten ohran ja kauran $\beta$-glukaanit ja rukiin ja vehnän arabinoksylaanit. Nämä aiheuttavat ruokasulan viskoottisuutta, mikä johtaa heikompaan ravintoaineiden imeytymiseen ja tahmaisiin ulosteisiin.

Broilereiden rehuihin lisätään yleisesti näitä hiilihydraatteja pilkkovia rehuentsyymivalmisteita. Samaa on sovellettu kalkkunoiden rehuihin, mutta tieteellistä tutkimusta entsyymien vaikutuksesta kalkkunoilla on tehty hyvin vähän. Tiedetään, että viskoottiset polysakkaridit ovat haitallisia erityisesti nuorille broilereille. Kalkkunoiden kasvatusikä on huomattavasti pitempi, eikä tietoa entsyymin vaikutuksesta eri ikäisillä kalkkunoilla ole. Tutkimuksen tarkoituksena oli määrittää ruokasulan viskositeetti, proteiinin ohutsuolisulavuus, rasvan kokonaissulavuus ja rehun muuntokelpoinen energia kalkkunoilta kolmessa eri ikävaiheessa syötettäessä maissia, vehnää, ohraa tai kauraa sellaisenaan tai entsyymillä täydennettynä.

\section{Aineisto ja menetelmät}

Kokeessa käytettiin 320 kasvavaa B.U.T. 8 -kalkkunaa. Koejaksot sijoittuivat 4, 8 ja 12 viikon ikään. Koejaksoilla linnuille syötettiin jauhettua, rakeistettua maissia, vehnää, ohraa tai kauraa $(\mathrm{M}, \mathrm{V}, \mathrm{O}, \mathrm{K})$ sellaisenaan tai Avizyme 1200:1la täydennettynä (+E). Rehuihin lisättiin sulamattomaksi merkkiaineeksi titaanioksidia.

Ulosteenkeruun perusteella määritettiin raakarasvan näennäinen kokonaissulavuus ja näennäinen typpikorjattu muuntokelpoinen energia $\left(\mathrm{AME}_{\mathrm{N}}\right)$. Ohutsuoliruokasulan viskositeetti, umpisuoliruokasulan haihtuvien rasvahappojen (VFA) määrä ja raakavalkuaisen näennäinen ohutsuolisulavuus märritettiin teurastustekniikalla. Tilastolliset testit suoritettiin SAS:n GLM-proseduurilla toistettujen mittausten analyysinä.

\section{Tulokset ja niiden tarkastelua}

Ruokasulan viskositeetti oli korkein O- ja V-dieeteissä, kohtuullinen K-dieeteissä ja matalin Mdieeteissä. Entsyymilisällä oli viskositeettia alentava vaikutus $(\mathrm{P}<0,001)$, mutta entsyymillä ja lintujen iällä oli yhdysvaikutusta, ja kauradieetissä entsyymi ei vanhemmilla linnuilla juuri vaikuttanut.

Umpisuoliruokasulan VFA-pitoisuus kasvoi iän myötä $(\mathrm{P}<0,001)$. Entsyymilisäys lisäsi VFA-tuotantoa $(\mathrm{P}<0,001)$, ja tämä vaikutus näytti voimakkaammalta vanhemmilla linnuilla $(\mathrm{P}<0,1)$. Umpisuolten lisääntynyt VFA-tuotanto näytti olevan lähinnä merkki täydellisemmästä rehun hiilihydraattien hyväksikäytöstä eikä epäsuotuisasta huonosti hyväksikäytettävien polysakkaridien fermentaatiosta.

Korkeimmat raakavalkuaisen ohutsuolisulavuudet havaittiin V-dieeteillä. M-dieeteillä sulavuus oli hieman heikompi $(\mathrm{P}<0,01)$ sekä $\mathrm{K}$ - ja erityisesti O-dieeteillä vielä heikompi $(\mathrm{P}<0,001)$. Oruokasulan viskoottisuus ilmeisesti heikentää sulavuutta. Toisaalta, myös entsyymitäydentämättömän V:n aiheuttama viskositeetti oli korkeahko, mutta silti raakavalkuaisen sulavuus oli lähes $90 \%$. Entsyymi paransi sulavuutta O:ssa ja K:ssa, mutta ei M:ssa ja V:ssä. Ikä vaikutti raakavalkuaisen ohutsuolisulavuuteen $(\mathrm{P}<0,001)$, ja trendi vaikutti laskevalta erityisesti 8 viikon jälkeen.

Entsyymilisäys paransi selvästi V:n ja O:n rasvan sulavuutta ja $\mathrm{AME}_{\mathrm{N}}$-arvoa, mutta ei vaikuttanut samoin K:ssa eikä erityisesti M:ssa, jonka energia-arvo oli korkea sellaisenaankin. Huomionar-

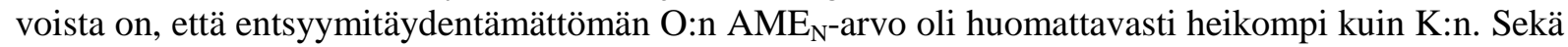
rasvan sulavuus että $A M E_{N}$-arvo paranivat merkitsevästi iän myötä $(P<0,001)$. Iän ja ruokinnan välillä oli kuitenkin yhdysvaikutusta $(\mathrm{P}<0,05)$, ja ohran heikommuus oli huomattavampaa nuoremmilla linnuilla. 